\title{
Standardization of method for lactoperoxidase assay in milk
}

\author{
Rajesh Kumar*, Krishan L. Bhatia \\ Dairy Chemistry Division, National Dairy Research Institute, Karnal 132001 (Haryana), India
}

(Received 5 March 1998; accepted 18 August 1998)

\begin{abstract}
The spectrophotometric method used to measure lactoperoxidase activity in milk was standardized. The assay system consisting of ABTS [2,2'-azinobis-(3-ethyl benzthiazoline-6-sulphonic acid)] as chromogenic substrate gave a linear initial rate of reaction up to $700 \mu \mathrm{g} \cdot \mathrm{L}^{-1}$ lactoperoxidase concentration, with maximum activity at $\mathrm{pH}$ 6.0. The lactoperoxidase activity was higher in buffalo milk than cow milk and the corresponding concentration of the enzyme was 31 and $24 \mathrm{mg} \cdot \mathrm{L}^{-1}$, respectively. A loss of $10-15 \%$ of peroxidase activity occurred on the preparation of rennet whey or acid whey. (C) Inra/Elsevier, Paris
\end{abstract}

lactoperoxidase assay / cow milk / buffalo milk / rennet whey / acid whey

Résumé - Standardisation de la méthode de dosage de la lactopéroxydase dans le lait. La méthode spectrophotométrique de dosage de l'activité de la lactopéroxydase dans le lait a été standardisée. La méthode, comprenant de l'ABTS [acide 2,2 ' azinobis - (3-ethyl benzthiazoline 6-sulfonique)] comme substrat chromogénique, donnait un taux initial de réaction linéaire jusqu'à une concentration en lactoperoxydase de $700 \mu \mathrm{g} \cdot \mathrm{L}^{-1}$, avec un maximum d'activité à pH 6,0 . L'activité de la lactopéroxydase dans le lait de bufflesse était supérieure à celle du lait de vache et les concentrations de l'enzyme étaient respectivement de 31 et $24 \mathrm{mg} \cdot \mathrm{L}^{-1}$. Une perte d'activité de la peroxydase de 10-15\% intervenait lors de la préparation de lactosérum présure ou de lactosérum acide. (C) Inra/ Elsevier, Paris

lactopéroxydase / lait de vache / lait de bufflesse / lactosérum présure / lactosérum acide

\footnotetext{
* Correspondence and reprints. rkb@ndri.kry.nic.in
} 


\section{INTRODUCTION}

Lactoperoxidase (EC 1.11.1.7) is an enzyme found in mammalian milk, saliva and tears. It is present in milk of different species in varying concentrations [12]. Lactoperoxidase acts in a system together with thiocyanate and hydrogen peroxide by catalysing the peroxidation of thiocyanate to putative antimicrobial hypothiocyanite ion [1]. The antimicrobial property of lactoperoxidase gives it a potential application in the preservation of raw milk under ambient conditions [8]. Methods available for the estimation of peroxidase activity are based on different donors such as $p$-phenylenediamine [2], pyrogallol and guaiacol [4, 10], ABTS [2,2' -azinobis-(3-ethyl benzthiazoline-6-sulphonic acid) $][9,10,14]$ and are, therefore, difficult to compare. The complex chemistry of peroxidation reactions requires that experimental conditions be carefully designed and rigorously controlled in order to obtain linear initial rates that are directly proportional to peroxidase concentrations. In the kinetic studies of lactoperoxidase catalysed reactions, Bardsley [3] specified the concentration $1 \mathrm{mmol} \cdot \mathrm{L}^{-1}$ ABTS, $0.1 \mathrm{mmol} \cdot \mathrm{L}^{-1}$ hydrogen peroxide and pH 5.6 as reaction conditions in assay, giving highest initial rate and minimal suicidal inhibition over a period of $2 \mathrm{~min}$. However, lactoperoxidase has been shown to be surface active [8]. At low concentration there is considerable reduction of enzyme activity in fluid phase because of adsorption of the enzyme on the container surface, which can be prevented by including gelatin in assay [10]. However, there is a practical difficulty in data acquisition because it requires a great deal of equipment. Therefore, a simple and convenient assay system was standardized using ABTS as chromogenic substrate by spectrophotometer. The distribution and level of lactoperoxidase in cow and buffalo milk was determined using this method.

\section{MATERIALS AND METHODS}

\subsection{Reagents}

\subsubsection{ABTS solution $\left(1 \mathrm{mmol} \cdot \mathrm{L}^{-1}\right)$}

Fifty-five mg of ABTS (Sigma) was dissolved in phosphate buffer $\left(0.1 \mathrm{~mol} \cdot \mathrm{L}^{-1}, \mathrm{pH} 6.0\right)$ and made up the volume to $100 \mathrm{~mL}$.

\subsubsection{Hydrogen peroxide solution $\left(0.1 \mathrm{mmol} \cdot \mathrm{L}^{-1}\right)$}

From the commercial hydrogen peroxide solution $30 \% \mathrm{v} / \mathrm{v}$ (Merck) a stock solution of $100 \mathrm{mmol} \cdot \mathrm{L}^{-1}$ was prepared by titrating against standard potassium permanganate solution. The stock solution was diluted to $3.2 \mathrm{mmol} \cdot \mathrm{L}^{-1} \mathrm{con}$ centration immediately before use.

\subsubsection{Peroxidase enzyme}

Lactoperoxidase from buffalo milk was purified to a purity index $A_{412} / A_{280}=0.94$ [6]. It was dissolved to concentrations varying from 10 to $800 \mu \mathrm{g} \cdot \mathrm{L}^{-1}$ in phosphate buffer saline containing $0.1 \%$ gelatin (PBSG) $\left(0.1 \mathrm{~mol} \cdot \mathrm{L}^{-1}, \mathrm{pH} 7.0\right)$.

\subsection{Peroxidase assay}

The ABTS solution $(3.0 \mathrm{~mL})$ and peroxidase sample $(0.1 \mathrm{~mL})$ were added together in a cuvette. The reaction was initiated by the addition of $0.1 \mathrm{~mL}$ of hydrogen peroxide solution and immediately the measurement of absorbance started at $412 \mathrm{~nm}$ as a function of time for $2 \mathrm{~min}$ at 10 -s intervals using Spectronic $21 \mathrm{D}$ spectrophotometer (Milton Roy). Measurements were carried out against the reagent blank containing ABTS and enzyme solution only.

\subsubsection{Unit of activity}

One unit of activity (U) is defined as the amount of enzyme that catalyses the oxidation of $1 \mu \mathrm{mol}$ of ABTS per min at $20^{\circ} \mathrm{C}$, in $0.1 \mathrm{~mol} \cdot \mathrm{L}^{-1}$ phosphate buffer $\mathrm{pH} 6.0$, using a concentration of $1 \mathrm{mmol} \cdot \mathrm{L}^{-1}$ ABTS and $0.1 \mathrm{mmol} \cdot \mathrm{L}^{-1}$ hydrogen peroxide in the reaction mixture. Taking the molar extinction coefficient of oxidized ABTS at $412 \mathrm{~nm}$ as $32400 \mathrm{~mol} \cdot \mathrm{L}^{-1} \cdot \mathrm{cm}^{-1}$ [15]. both at $\mathrm{pH}$ 6.0 and 4.4 , the activity expressed in $\mathrm{U} \cdot \mathrm{mL}^{-1}$ was calculated according to Putter and Becker [11]. 
Change in absorbance at $412 \mathrm{~nm} x$ assay volume, $\mathrm{V}(\mathrm{mL})$

Extinction coefficient $\left(1 \mathrm{mmol}^{-1} \mathrm{~cm}^{-1}\right) \times$ sample volume, $\mathrm{v}(\mathrm{mL}) \mathrm{x}$ time, $\mathrm{t}(\mathrm{min})$

The enzymatic reaction of lactoperoxidase with ABTS as substrate takes place as follows:

$2 \mathrm{ABTS}+\mathrm{H}_{2} \mathrm{O}_{2} \rightarrow 2 \mathrm{ABTS}^{+}+2 \mathrm{H}_{2} \mathrm{O}$

since the degradation of $1 \mathrm{~mol}$ of hydrogen peroxide yields $2 \mathrm{~mol}$ of oxidized ABTS. Therefore, the stoichiometric coefficient $v_{i}=2$ was taken in the denominator of the above relation. Using the above volumes, it becomes

$\frac{\Delta \mathrm{A}_{412} \times 3.2 \times 1}{32.4 \times 0.1 \times 1 \times 2}=0.4938 \times \Delta \mathrm{A}_{412} / \mathrm{min}$ Units of $32.4 \times 0.1 \times 1 \times 2$ lactoperoxidase $/ \mathrm{mL}$ of sample

\subsection{Milk samples}

Pooled milk samples were collected from Murrah buffaloes and crossbred cows maintained at the National Dairy Research Institute (Karnal, India). The samples were skimmed using Alfa Laval cream separator.

\subsubsection{Whey samples}

The rennet whey was prepared from skim milk by adding Meito rennet at the rate of $20 \mathrm{mg} \cdot \mathrm{L}^{-1}$ and incubating at $30{ }^{\circ} \mathrm{C}$ for $30 \mathrm{~min}$. After setting, the curd was cut and the whey was filtered using a Whatman No. 1 filter paper. For acid whey, the skim milk was diluted $1: 1$ by distilled water and acidified to $\mathrm{pH} 4.6$ using $2 \mathrm{~N} \mathrm{HCl}$. The clear whey was obtained by filtration through Whatman No. 1 filter paper.

\subsubsection{Peroxidase activity}

Ten samples each from cow and buffalo whole milk, skim milk, rennet whey and acid whey were analyzed for peroxidase activity after dilution $(1: 250)$ with PBSG $\left(0.1 \mathrm{~mol} \cdot \mathrm{L}^{-1}\right.$, $\mathrm{pH} 7.0$ ) both at assay $\mathrm{pH} 6.0$ and 4.4 .

\section{RESULTS AND DISCUSSION}

\subsection{Calibration curve for peroxidase assay}

The reaction rate was a linear function of enzyme concentration from $10-700 \mu \mathrm{g} \cdot \mathrm{L}^{-1}$ (figure 1) with the corresponding constant reaction rate varying from 0.007 to 0.35 up to $2 \mathrm{~min}$. Thus, it was inferred that for estimation of lactoperoxidase activity in milk or whey, the samples should be diluted using PBSG to bring the observed reaction rate in this range.

\subsection{Effect of $\mathrm{pH}$ on assay}

The $\mathrm{pH}$ was varied from 4.0-8.0 using $0.1 \mathrm{~mol} \cdot \mathrm{L}^{-1}$ acetate buffer $/ 0.1 \mathrm{~mol} \cdot \mathrm{L}^{-1}$ phosphate buffer at a lactoperoxidase concentration of $0.4 \mu \mathrm{g} \cdot \mathrm{mL}^{-1}$ (prepared by 250 -fold dilution of stock solution $100 \mu \mathrm{g} \cdot \mathrm{mL}^{-1}$ ). The highest peroxidase activity was observed at $\mathrm{pH} 6.0$ (figure 1, table I). In cervical mucus, $\mathrm{pH} 4.4$ was recommended for assay of peroxidase activity [15]. However, on low dilution of milk samples this $\mathrm{pH}$ poses difficulty in the analysis due to precipitation of milk proteins. Therefore, $\mathrm{pH} 6.0$ is a better choice for the estimation of peroxidase activity in milk.

\subsection{Effect of thiocyanate on assay}

The average content of thiocyanate in milk samples analyzed for peroxidase activity was $0.1 \mathrm{mmol} \cdot \mathrm{L}^{-1}$. It has been reported that $0.1 \mathrm{mmol} \cdot \mathrm{L}^{-1}$ thiocyanate in milk can result in $10 \%$ reduction in the observed rate [9]. Since the milk samples were diluted 250 -fold for peroxidase assay, the corresponding thiocyanate content was reduced to $0.4 \mu \mathrm{mol} \cdot \mathrm{L}^{-1}$. To determine the effect of thiocyanate at this level, $0.1 \mathrm{mmol} \cdot \mathrm{L}^{-1}$ thiocyanate was added to $100 \mu \mathrm{g} \cdot \mathrm{mL}^{-1}$ lactoperoxidase solution. It was diluted to 250 -fold using PBSG (0.1 mol. $\left.\mathrm{L}^{-1}, \mathrm{pH} 7.0\right)$ and analyzed for peroxidase activity. The reduction in the observed rate was below $0.05 \%$. Hence, there was only a negligible effect of thiocyanate on the assay system.

\subsection{Distribution and level of lactoperoxidase in milk}

On separation of milk the peroxidase activity was found to increase slightly both 


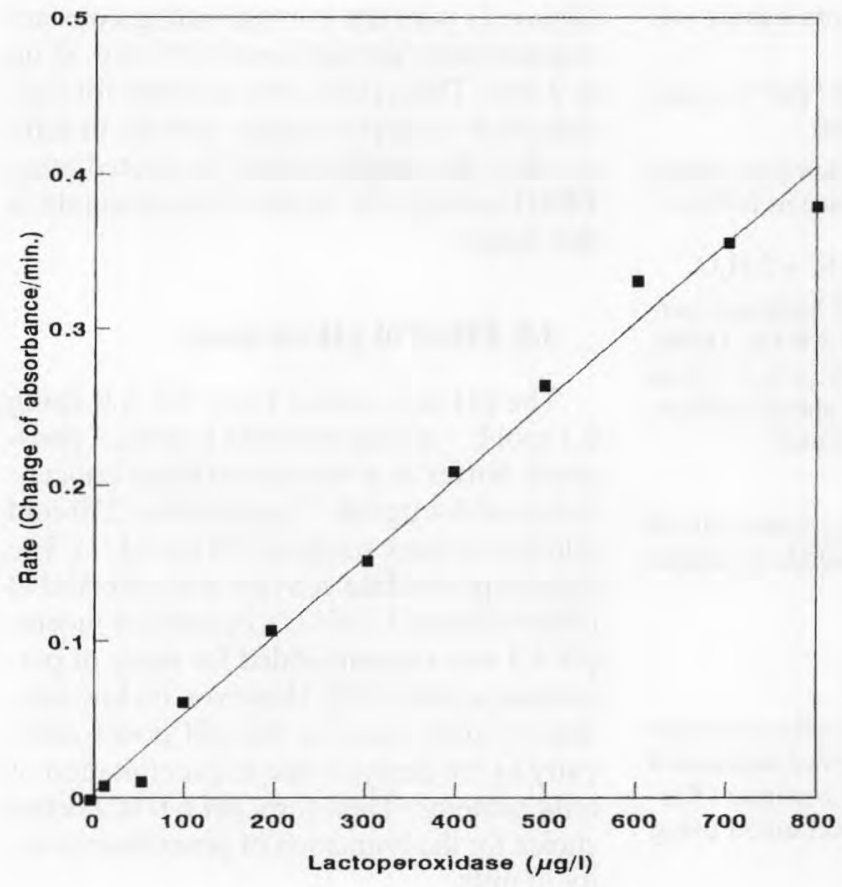

Figure 1. Standard curve for lactoperoxidase assay.

Figure 1. Courbe standard de détermination de la lactopéroxydase.

Table I. Distribution of lactoperoxidase in milk.

Tableau I. Distribution de la lactopéroxydase dans le lait.

\begin{tabular}{lccccc}
\hline Species & Assay $\mathrm{pH}$ & \multicolumn{4}{c}{ Peroxidase activity $\left(\mathrm{U} \cdot \mathrm{mL}^{-1}\right)^{*}$} \\
\cline { 3 - 6 } & & Whole milk & Skim milk & Rennet whey & Acid whey \\
\hline Buffalo & 4.4 & $1.371 \pm 0.262$ & $1.495 \pm 0.129$ & $1.252 \pm 0.152$ & $1.182 \pm 0.427$ \\
& 6.0 & $7.315 \pm 0.134$ & $7.720 \pm 0.109$ & $6.913 \pm 0.188$ & $6.786 \pm 0.114$ \\
Cow & 4.4 & $1.263 \pm 0.227$ & $1.355 \pm 0.160$ & $1.114 \pm 0.245$ & $1.095 \pm 0.163$ \\
& 6.0 & $5.724 \pm 0.274$ & $5.973 \pm 0.147$ & $5.251 \pm 0.196$ & $5.135 \pm 0.180$ \\
\hline
\end{tabular}

* Mean of ten observations \pm standard error.

* moyenne et écart type de dix observations.

in cow and buffalo milk samples (table I). Furthermore, on preparation of acid whey and rennet whey, about 10-15\% loss of activity was observed. The increase in peroxidase activity on skimming might be due to an effective increase in concentration of lactoperoxidase corroborating that the enzyme is mainly present in the serum phase [13]. The peroxidase activity was observed to be higher in buffalo milk than cow milk both at $\mathrm{pH} 6.0$ and 4.4, which is in contrast to an earlier report [5] showing higher peroxidase activity in cow milk $\left(1.2 \mathrm{U} \cdot \mathrm{mL}^{-1}\right)$ than buffalo milk $\left(0.9 \mathrm{U} \cdot \mathrm{mL}^{-1}\right)$ at $\mathrm{pH} 4.4$. 
Figure 2. Effect of $\mathrm{pH}$ on lactoperoxidase assay.

Figure 2. Effet du pH sur l'activité de la lactopéroxydase.

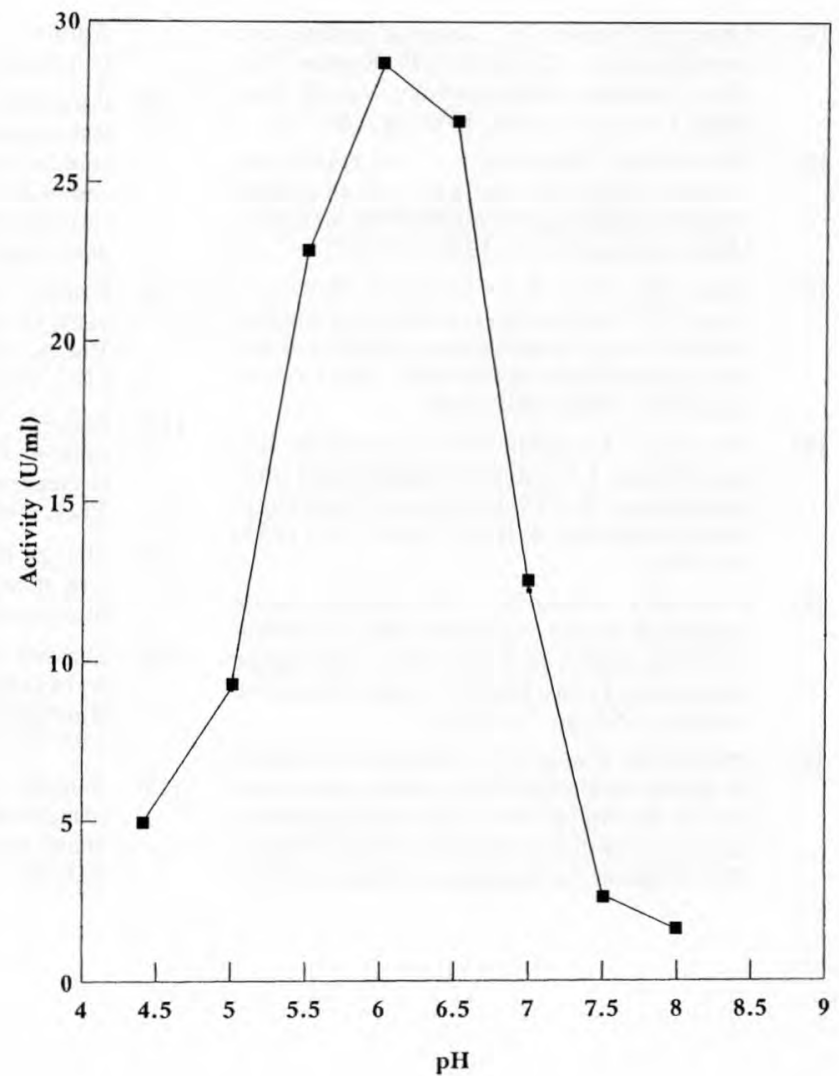

In cow milk the peroxidase activity observed at $\mathrm{pH} 4.4$ was similar [12].

Based on the reaction rate of lactoperoxidase in buffalo milk and cow milk, its concentration was determined to be 31 and $24 \mathrm{mg} \cdot \mathrm{L}^{-1}$, respectively. However, the level of lactoperoxidase in cow milk has been reported to be slightly higher $\left(30 \mathrm{mg} \cdot \mathrm{L}^{-1}\right)$ [7].

\section{CONCLUSION}

The assay conditions employed in the method for peroxidase estimation gave a linearity of initial reaction rate of up to 2 min with a negligible effect of thiocyanate and the peroxidase activity was around fivefold higher at $\mathrm{pH} 6.0$ than at $\mathrm{pH} 4.4$ both in cow and buffalo milk and whey samples.

\section{REFERENCES}

[1] Aune T.M., Thomas E.L., Accumulation of hypothiocyanite ion during peroxidase catalysed oxidation of thiocyanate ion, Eur. J. Biochem. 80 (1977) 209-214.

[2] Aurand L.W., Roberts W.M., Cardwell J.T., A method for estimation of peroxidase activity in milk, J. Dairy Sci. 39 (1956) 568-573.

[3] Bardsley W.G., Steady state kinetics of lactoperoxidase catalysed reactions, in: Pruitt K.M., Tenovuo J.O. (Eds.), The Lactoperoxidase System, Marcel Dekker, New York, 1985 , pp. 55-87. 
[4] Chance B., Maehly A.C., Assay of catalases and peroxidases, in: Colowick S.P., Kaplan N.O. (Eds.), Methods in Enzymology, Vol. II, Academic Press, New York, 1955, pp. 764-775.

[5] Harnulv B.G., Kandasamy C., Increasing the keeping quality of raw milk by activation of the lactoperoxidase system: results from Sri Lanka, Milchwissenschaft 37 (1982) 454-457.

[6] Kumar R., Bhatia K.L., Dauter Z., Betzel C., Singh T.P., Purification, crystallization and preliminary $\mathrm{x}$-ray crystallographic analysis of lactoperoxidase from buffalo milk, Acta Crystallogr. D 51 (1995) 1094-1096.

[7] Polis B.D., Shmulker H.W., Crystalline lactoperoxidase. I. Isolation by displacement chromatography. II. Physico-chemical and enzymatic properties, J. Biol. Chem. 201 (1953) 475-500.

[8] Pruitt K.M., Kamau D.N., The lactoperoxidase systems of bovine and human milk, in: Robinson D.S., Eskin N.A.M. (Eds.), Oxidative Enzymes in Foods, Elsevier Applied Sciences, London, 1991, pp. 133-174.

[9] Pruitt K.M., Kamau D.N., Quantitative analysis of bovine lactoperoxidase system components and of the effects of the activated system on bacterial growth and survival, in: Proceedings of IDF Seminar on Indigenous Antimicrobial
Agents of Milk - Recent Developments, Uppasala, Sweden, 1993, pp. 73-87.

[10] Pruitt K.M., Kamau D.N., Miller K., ManssonRahemtulla B., Rahemtulla F., Quantitative, standardised assays for determining the concentrations of bovine lactoperoxidase, human salivary peroxidase and human myeloperoxidase, Anal. Biochem. 191 (1990) 278-286.

[11] Putter J., Becker R., Peroxidases, in: Bergmeyer H.U. (Ed.), Methods of Enzymatic Analysis, Vol. 3, 3rd edn., Verlag Chemie, Weinheim, FRG, 1983, pp. 286-293.

[12] Reiter B., The lactoperoxidase system of bovine milk, in: Pruitt K.M., Tenovuo J.O. (Eds.), The Lactoperoxidase System, Marcel Dekker, New York, 1985, pp. 123-141.

[13] Sharma R.S., Ganguli N.C., Distribution pattern of certain enzymes in buffalo milk, Enzymologia 40 (1971) 337-344.

[14] Shindler J.S., Bardlsey W.G., Steady state kinetics of lactoperoxidase with ABTS as chromogen, Biochem. Biophys. Res. Commun. 67 (1975) 1307-1312.

[15] Shindler J.S., Childs R.E., Bardsley W.G., Peroxidase of human cervical mucus. Isolation and characterisation, Eur. J. Biochem. 65 (1976) 325-331. 